\title{
Refugeehood and Rights: A Theoretical Debate ${ }^{1}$
}

\author{
Leonardo Barros da Silva Menezes ${ }^{\mathrm{I}}$ (ID
}

\section{Introduction ${ }^{1}$}

States have primary responsibility for ensuring their own citizens' enjoyment of human rights. Sometimes, though, this contract assumed between state and citizenry breaks down for a number of reasons - due to malevolence, incompetence, or lack of capacity, many governments cease to guarantee to their citizens the basic conditions for human dignity. Under these circumstances, people who do not have access to basic human rights in their own country, and then are forced to escape those dire conditions, are legally and morally entitled to flee for their lives. This situation of (forced) displacement is widely recognized as a key aspect of what makes an international society of states both legitimate and civilized, as it represents the invaluable safeguard of the ultimate value of human life against unjust or institutionally failed governments.

The continuity of the modern refugee regime, since at least the Second World War' aftermath, has faced new challenges, mostly coming from its own historically and politically dated formulation. Initially conceived to ensure that states would no longer return refugees present on their territory, the 1951 Convention on the Status of Refugees, among other measures as, for example, the creation of the Office of the United Nations High Commissioner for Refugees (UNHCR), clearly established who ought to be legally recognized as a refugee and to which rights those people would be entitled (Haddad, 2008; Loescher, 2010). The purpose was first and foremost to provide shelter for people who cannot have access to their most basic rights within their country of origin and would then have the right to safely enjoy these rights elsewhere. Still, what was once a precise definition of who would qualify for access to asylum, that is, those fleeing persecution by their own government, turned out to be one of today's main global and domestic politics issues, as the circumstances forcing someone to flee have dramatically changed. Factors such as generalized violence, environmental changes and food insecurity have been at the roots of a growing proportion of an unpredictable geographical trend of crossborder displacement.

Furthermore, the outlines of a (post) pandemic regime of global mobility are yet unclear, and the public health crisis dramatically worsened pre-existing trends towards more restrictive and repressive modes of enforcement, prompting a massive shutdown of borders. In this context, the UNHCR estimated that of the 167 countries who had fully or partially closed their borders to stop the spread of the virus, 57 made no exception for people seeking asylum (UNHCR, 2020) ${ }^{2}$. Our hope is that, in the aftermath of a crisis that threatened the freedom of so many

1 This paper was based on the first chapter of my Master Thesis at Sciences Po (Institut d'Études Politiques de Paris), entitled "The Morality of Encampment: Refugeehood, Politics and Global Justice” (2020).

2 I am especially indebted to the reviewer who suggested a brief description of the refugee crisis in the covid-19 pandemic context.

${ }^{\mathrm{I} C e n t r e ~ f o r ~ E t h i c s, ~ P o l i t i c s ~ a n d ~ S o c i e t y, ~ U n i v e r s i t y ~ o f ~ M i n h o ~-~ B r a g a, ~ P o r t u g a l . ~ E-m a i l: ~ l e o n a r d o b s m e n e z e s @ g m a i l . c o m ~}$ Received on: 20/12/2020. Approved on: 27/05/2021. 
citizens around the world, we will be led to rethink the immense harm caused by border closures. There is an urgent need for effective international co-ordination of migration and asylum, with the perspectives of those most directly impacted by border controls included as a matter of justice.

Almost 70 years after Hannah Arendt famously observed that refugees are the "most symptomatic group in contemporary politics" (Arendt, 1986, p. 277), one question that immediately comes to mind today is: Who is a refugee? In face of so many desperate plights, virtually all legal, moral and political philosophers agree that (host) states have a moral duty to offer asylum: people simply cannot be forced back to countries where they would face persecution or severe human rights violations (Carens, 2013; Gibney, 2004; Miller, 2016; Price, 2009). However, this consensus conceals a number of thorny ethical issues raised by the plight of the displaced. Perhaps the most controversial issue in recent debates is "what exactly do we owe to victims of forced displacement?" The worldwide refugee crisis brought this question to life, so to speak, as many of the world's liberal democracies have been struggling to balance humanitarian impulses to help with opposing political values like security and sovereignty. This paper examines how we can begin to understand our moral obligations towards the forcibly displaced and how to ground such obligations so that in the face of what might seem to be competing demands nationalism, security, the economy - they may nonetheless be taken seriously into consideration. Initially, I examine analytic philosophers' attempts at proposing a moral definition of refugee (entitlement) and how states' sources of obligations, more precisely the notion of humanitarianism, relates to states' responses to forced displacement. In doing so, I demonstrate that, although each one of these definitions suggests a reasonable justification for these obligations, they cannot provide a full response to refugeehood in today's world. Next, I analyze how Critical Citizenship Studies and renewed investigations of Hannah Arendt's thought have focused on the political issue of statelessness posed by the humanitarian challenge of displacement. Whereas this philosophical framework rightly emphasizes the importance of the refugees' right to political participation in the (inter) national community, its response cannot avoid the (political) problem of supporting without distinction the granting of citizenship to stateless persons without due consideration of states' limited resources in terms of rights and goods. Finally, I present an outline of these two contrasting perspectives of refugeehood, in which states' minimal moral duties usually conflict with refugees' appeal to positive rights. By doing so, I draw attention to our current challenge of either reforming the institution of refugeehood by providing humanitarian rights to more displaced people, or replacing our refuge system by imposing more demanding norms of justice upon states - at the risk of protecting fewer persons.

\section{Legal and moral philosophy: who is a refugee?}

What social impact would taking in large numbers of refugees in a short space of time have on any society? Even though the unprecedent events of 2015, when more than a million foreigners entered Europe and found sanctuary there, are unlikely to be repeated, it is the global minority attempting to settle in the global North who have been capturing most of philosophers' attention and reflections on the moral and political claims of refugees. This fact is not irrelevant to the manner in which analytic philosophers have been dealing with states' obligations towards displaced 
persons. In other words, my assumption is that the theories I examine below, which range from a kind of sufficientarianism to a capability approach, cannot surpass the very terms of the debate, which has important theoretical as well as political implications regarding how to respond to forced displacement around the world.

Drawing on a range of perspectives, some taking a more expansive and some a more restrictive view of the claims that refugees can make and of the state's obligations toward them, I present two basic, interrelated questions that analytic philosophers have been trying to respond, namely, "What are the root causes that lead to a citizen becoming an asylum-seeker?;" and most importantly, "Who is a refugee? (Or, more precisely, who should be entitled to asylum?)." The definition of the refugee status in international law became a reality only due to the post-war Convention Relating to the Status of Refugees at Geneva in 1951. Although the adherence of a number of states did not end the political disagreement about who should qualify as a refugee, a series of definitions, which I classify below in four distinct groups, still aim at solving this question. Besides presenting each one of these conceptual frameworks, from the most restrictive definition to the broadest one, I also briefly address some endogenous criticisms of one analytic model to another.

Figure 1. Refugee: A spectrum of definitions.

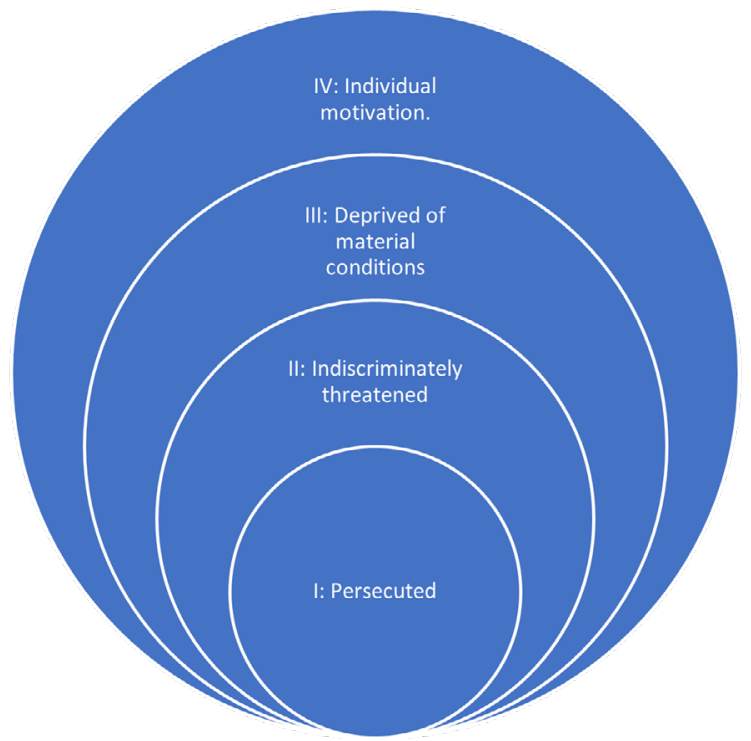

Source: based on Menezes (2020).

I: Persecuted. The most restrictive definition, which formally remains the one used in international law, originates in the Geneva Convention. Under this perspective, a refugee is a person who "owing to a well-founded fear of being persecuted for reasons of race, religion, nationality, membership of a particular social group or political opinion, is outside the country of his nationality and is unable or, owing to such fear, is unwilling to avail himself of the protection of that country" (Hathaway, 2005, p. 96-97). 
Those who support the Convention-based definition emphasizes the dividing line between persecuted and non-persecuted refugees in that it singles out a class of people whose bonds to their political community have been shattered ${ }^{3}$. Matthew Price (2009), in particular, traces the asylum's political roots back to a judgement about the rightfulness of a state's exercise of authority. Because granting asylum interferes with that exercise, he argues, it has basically involved two aspects: (i) its historical function was to give fugitives immunity from unjust punishment and, simultaneously, (ii) by identifying persecution as the essential criterion for granting refugee status, it has served the political purpose of condemning states at the international level. In this sense, asylum is an unavoidable issue when it comes to legitimize foreign interventions in a given country, which would also extend its essential applicability from the Cold War era to our days. Price then criticizes what he calls the state's humanitarian approach in which persecuted as well as nonpersecuted refugees would be granted the same status. This approach, according to Price, eliminates any expressive valence from asylum as a form of sanction for abuses committed by governments against their citizens.

Curiously though, Price aims to avoid the "overpoliticization" of refugeehood by recognizing that states might be unwilling to grant asylum to displaced people from friendly governments, or that they might be too willing to "overprotect" those who are persecuted by hostile countries. As a solution to this issue, he dedicates nothing but a few lines on matters of institutional design, where he argues for the insulation of asylum adjudicators from political interference, so that asylum decisions would reflect genuine normative judgements about the nature of the harm faced by applicants. Still, this rests on the assumptions that (i) geopolitical asymmetries could be fairly addressed, or at least politically manageable, and that (ii) investing asylum with political significance is feasible when technical considerations paradoxically water down the asylum political dynamics. Furthermore, what seems mostly disputable for our present purposes is the fact that Price and supporters of the Convention-based definition often have a shortsighted understanding of "persecution" when they omit other causes that might force someone to flee their home country $^{4}$ (UNHCR, 2011, p. 19).

II: Indiscriminately threatened. Consider, for example, the following case: a rebel's wife who has never taken part in the political resistance and, in principle, has not caught the state's eyes in its counteroffensive. In this case, she may just be a bystander whom neither side is targeting directly, so she would not qualify as a victim of persecution. Nevertheless, her life might, and probably would, be at risk so long as she remains where she is. UNHCR aims to take these cases into account by adopting a broader definition: alongside those who are entitled to refugee status for having fled their country out of fear of persecution are those "who are unable to return there owing to serious and indiscriminate threats to life, physical integrity or freedom resulting from generalized violence or events seriously disturbing public order"s. Definition II, then, extends the scope to someone who finds

3 "Asylum responds not only to victims' need for protection, but also to their need for political standing, by extending membership in a new political community" (Price, 2009, p. 248).

4 Another aspect of persecution refers to discriminatory employment practices aimed at the social, ethnic, religious groups mentioned in the Convention.

5 This is also the definition underlying the UN Global Compact for Refugees, adopted in 2016 and on its way to be signed by member states. See www.unhcr.org/gcr/GCR_English.pdf 
herself or himself under (life, bodily security or freedom) threat, regardless of whether this results from deliberate persecution or from social and political upheavals as in the hypothetical case mentioned above ${ }^{6}$.

This broad definition of "refugee" has not gone unchallenged. Supporters of the definition usually draw attention to the particular burden of those who are (in)directly persecuted, as is the case in the loss of membership in a political community. This is what makes special their claim to human rights' protection: by being admited to a new home their political agency can also be restored. Matthew Price, as mentioned above, emphasizes the political importance of preserving asylum granting only to persecuted refugees for instrumental reasons in the international context. But this position explicitly rests on restricting the designation to those who are escaping state-sponsored persecution. From another theoretical perspective, however, what is at stake in defining refugeehood depends on the actual severing of social bonds. Under this perspective, persecution as such fails to capture the phenomenon of displacement in its broader manifestation: by taking into account the absence of state protection it says nothing about the citizen's basic needs.

III: Deprived of material conditions. Definition II is, thus, supposedly too narrow, as it leaves out certain conditions that might provide compelling reasons to grant someone the refugee status. Consider someone whose subsistence is threatened because of a genuine resource scarcity like unproductive land. If his or her severe poverty or situation of environmental degradation, which hamper the satisfaction of basic needs, is a result of human (political) mismanagement, should he or she not also count as refugee as well? This is how Andrew Shacknove formulates the definition III, according to which refugees are "persons whose basic needs are unprotected by their country of origin, who have no remaining recourse other than to seek international restitution of their needs, and who are so situated that international assistance is possible" (Shacknove, 1985, p. 277).

By viewing refugeehood under the perspective of persecution, natural calamities and failures to provide minimal subsistence, Shacknove argues that the only reason for restricting the status to those facing persecution derives from the states' fear of unilaterally bearing the burden of providing for refugees, which would explain their attempt to resolve an institutional problem by a legalistic sleight of hand. According to Shacknove, what matters mostly is the fact that the refugees' home state cannot provide for their needs, while other states or international agencies can. Yet, are all persons deprived of their basic needs (to be considered as) refugees? More than the well-known criticism of definition III by international lawyers, on the grounds that it is much harder to establish whether it is strictly necessary for someone to migrate in order to meet their basic needs, it is Shacknove himself who seems to lack a clear definition of who a refugee is after all. To do so, he vaguely attempts to distinguish refugees from deprived persons in light of their differing position vis-à-vis the international community and their own government. In his rather inaccurate words, being a refugee "is not a matter of entitlements that distinguishes refugees from all other persons whose basic needs are unmet by their home government but a matter of dissimilar objective conditions," which means

$6 \quad$ To insist that a refugee must be deliberately targeted is a mistake. From a moral perspective, what is most important here is the severity of the threat to basic human rights and the degree of risk rather than the source or character of the threat. 
that "refugees, unlike all others deprived of their basic needs, have a well-founded fear that recourse to their own government is futile and are, in addition, within reach of the international community" (Schacknove, 1985, p. 282). But an obvious question here remains unanswered: Why, and how (in practice), do these supposedly "objective conditions" vis-à-vis the international community define a refugee qua refugee?

IV: Individual motivation. After examining the limits of definition III, another possible question that might arise is: Why not to accept that all those whose motivations for pursuing a better life if they were strong enough to led one to emigrate? In short: Who has a compelling claim to be admitted to our society? Concerning the definition IV, all people who have such a claim should be considered a refugee regardless of the particular reason for migrating. Under this perspective, the difference between refugees and economic migrants is not a matter of kind, but of degree. Yet, even a supporter of this view like Jose Carens considers that some selection is unavoidable in any society, so that refugees' claim should be given priority because of the higher level of moral urgency of her or his plight. Hence, one criterion for assessing the applicability of the definition IV is to regard all those who undertake dangerous journeys to the borders of the countries to which they wish to emigrate as refugees. For Carens, the issue is not how we can best address poverty or environmental degradation in general, but rather: What do we owe to the particular person who has asked on such grounds to be admitted to our society ${ }^{7}$ ? By evaluating the seriousness of the reason for migrating according to the needs and interests of the migrant, Carens attempts to respond to Shacknove's distinction between refugees and migrants who supposedly would not have sufficient reasons for claiming asylum in another country. In short, if someone is fleeing from dire social conditions in search of a better life, the fact that he or she could possibly have better prospects while remaining in situ is irrelevant. But it seems pretty intuitive to question ourselves why, from a moral point of view, should host states pay special attention to those who have chosen to migrate, as opposed to those who remained in their home countries, even when the latter face the same hardships. Another issue emerges from that same normative solution: To what extent accepting those who crossed the borders of a receiving country would not result in a "geographical bias" when considering those who are not able to leave?

\section{The source of state's obligations to refugees}

What, then, do analytic philosophers derive in terms of state's ethical obligations to refugees from this scenario? From a legal standpoint, the obligations that states bear toward asylum claimants are relatively narrow, as they usually ascertain whether the person in question is entitled according to Definition I. If a state must protect the asylum-seekers' human rights during the processing of the case, when the principle of non-refoulement begins to apply, either on a permanent/ temporary basis or through a transfer to a safe third country, things work a little bit different when refugees are still on their way. First, there is no legal obligation to facilitate the refugees' trip to a border crossing, which explains why states have adopted a range

7 "From a moral perspective, what is most important is the severity of the threat to basic human rights and the degree of risk rather than the source or character of the threat" (Carens, 2013, p. 201). 
of restrictive measures by implementing non-entrée policies (Gammeltoft-Hansen; Hathaway, 2004), all designed to limit and make more difficult for refugees' to flow into their territories. Second, providing the means for migrants to cross borders or the high seas is not among a state's legal obligations either.

When it comes to moral obligations to refugees, the scope of action may go beyond these narrow legal duties. But from where do these moral obligations come? I briefly outline three main sources here: (a) humanitarianism; (b) the system of states; and (c) the burdensharing scheme ${ }^{8}$.

a. Humanitarianism sees refugees as people in dire need who require another state to stretch its resources and meet their needs. Humanitarian obligations do not mean a state have no discretion over when and how to comply with them. This approach thus understands we have an indeterminate obligation to human beings in need. Ultimately, each state can exercise their benevolence according to its own judgement on a given issue, by defining the amount of resources either to enforce or grant asylum rights or to invest these finite resources in developing/ underdeveloped countries in order to tackle global poverty.

b. A second way of understanding obligations to refugees is to look at them through the lens of the entire system of states in its current form. Given that states now claim jurisdiction over the entire habitable surface of the earth, a refugee cannot move but from one state to another. Under this perspective, the cost states impose by grabbing all earth's surface to the detriment of an individual's natural right to wander freely means, in the case of those who have nowhere to escape unless another state provides refuge, that a compensation for refugees' loss of freedom must be set out by granting them rights of entry, simply because there is no terra nullius.

c. The burden-sharing scheme understands state's obligations to refugees as a reciprocity-based practice to which all states are nominally committed, thereby viewing refugees' protection as a collective responsibility. All states with the capacity to respond should then support or receive a certain number of refugees. Refraining from violating human rights of foreigners would not thus be enough: states must acknowledge having a positive obligation to help protect them. Therefore, this human rights approach relies primarily on the states' duty under the international order to enforce the rights of non-citizens, then to stand a challengeable assumption about interstate reciprocity.

\section{Humanitarianism}

First, in an academic investigation like this one, my aim is to clarify as ideal-types the many ways in which moral and legal philosophers have conceptually delineated the issues mentioned above, before addressing the question of what should be done in practice. The question of feasibility helps us here to understand how some authors derive their normative claims from the principle of humanitarianism in order to establish a model of how state responds to refugeehood. In addition, I elucidate at the same time its weaknesses and omissions

8 All criticism I address in this work concerns exclusively how analytic philosophers have formulated as a matter of principle a defense of (a) Humanitarianism. 
and, consequently, its political implications. Clearly, for a cosmopolitan like Carens the focus on the seriousness of the moral claim is more important than the state's right to exercise discretionary authority over immigration. Thus, the seriousness of refugees' claims is not affected, in principle, by the number of claimants. Other philosophers, by contrast, adopt another approach.

In his attempt to adapt Shacknove's definition of refugee (III) to a humanitarianbased response - on the assumption that any state's ethical response to refugee issues must take into account domestic political stability (electoral politics) and scarce resources (economic interests) - Matthew Gibney (2004) takes a broader view of the source of state obligations by including another condition, namely that a person's basic needs can only be met by being granted admission to another state. Humanitarianism thus argues that "states have an obligation to assist refugees when the costs of doing so are low" (Gibney, 2004, p. 231). This principle - he assumes - bridges the gap between communitarians and (global) liberals as it extends the duties stemming from membership in a single human community, but not without specifying, less comprehensibly, obligations only to those in great need. This "low cost" expansion echoes, although with different normative implications, Michael Walzer's analogous principle of mutual aid'. Given his approach, one could say that states are generally free to shape entry policies according to their own criteria, but in dealing with refugees the entry procedures should be designed in such a way that their entering the country does not disturb the receiving-state citizens' cultural life. A form of sufficientarianism is reflected in Gibney's view, particularly because humanitarian duties as they are understood should not be so demanding as to prevent the fulfillment of the state's commitments (such as ensuring its own citizens' welfare); positive assistance duties to outsiders are owed exclusively to those in great need. In this sense, the criterion for accepting more or less refugees is directly related to a trade-off between (economic as well as political) domestic costs and the duty to help foreigners. Whereas Gibney's "low cost" proviso supposedly serves as a way of keeping at a minimum the burden upon citizens, it aligns moral demands upon states with what politics makes possible at a given time, thus allowing any state to apply this principle according to a particular country's prevailing circumstances (Gibney, 2004, p. 233 234). In attempting to reshape the political environment that governments face in ways more conducive to the protection of refugees, respecting this humanitarian principle does not, however, necessarily oblige states to dismantle non-arrival measures ${ }^{10}$. The underlying assumption here is that the abolition of non-arrival measures would worsen the asylum-seekers' already wretched conditions, as "under a less restrictive regime, more people would be tempted to use the services of smugglers and embark upon the kind of hazardous sea crossings" (Gibney, 2004, p. 238).

Maintaining asylum's traditional focus on assisting persecuted people in opposition to non-persecuted ones involves similar underlying assumptions about the costs of protecting refugees, but has distinct implications regarding the duties that a state owes to them in humanitarian terms. Supporters of the most restrictive definition

9 "[This principle] is more coercive for political communities than it is for individuals because a wide range of benevolent actions is open to the community which will only marginally affect its present members [...]" (Walzer, 1983, p. 45).

10 "In contrast to a right of free movement, for example, humanitarianism mainly offers a framework within which a state is required to assess and defend its response to refugees" (Gibney, 2004, p. 236). 
(I) of refugee entitlement defend deterrence measures as a means of reducing incentives to "economic migrants" submit fraudulent or bad faith asylum applications. Without such (political as well as administrative) procedures, nothing but chaos would supposedly result, given the rising number of "non-genuine" claims, even if the substantive grounds for eligibility are broadened. Under this perspective, an influx of asylum seekers would invite a backlash because it would raise doubts about the effectiveness of border controls, thus undermining the domestic public support for asylum and, consequently, the very persecution-based asylum system on which "genuine" claimants rely ${ }^{11}$.

This is what allows Matthew Price to defend such a narrow definition of asylum as the persecution-based one. On the practical assumption that "states are justified in choosing to spread scarce resources broadly by offering remedies [which are] less costly" (Price, 2009, p. 168), non-persecuted refugees would be given nothing beyond a temporary protection. After all, he argues, they "retain standing as members in their states of origin even when they are exposed to serious harm" (Price, 2009, p. 168). Full citizenship- or "surrogate membership" in this sense is precisely what persecuted refugees are owed, mainly because their claim to asylum is not founded on a derivative right related to claims like indiscriminate threats (to life) or severe poverty; rather, it supposedly originates in the only legitimate reason for being a member of another society. At the same time, there is an instrumental reason for granting such a special right to the persecuted: by recognizing the moral distinctiveness of this root cause for displacement, the international community justifies its political role (function) of taking action against authoritarian regimes. In short, the unequal amounts of goods distributed among persecuted and nonpersecuted (displaced) persons, according to Price, relies upon both the assumption of a state having limited resources and the distinctively moral-political character of persecution at the international level.

Nevertheless, unlike other supporters of Definition I (Hathaway, 2005), Price is well aware that neither temporary asylum nor membership could provide by themselves a fully compelling reasoning for granting refugeehood. In other words, how could one respond to the "proximity bias" when asylum is only available to refugees who manage to enter the territory of the state of refuge - though they might not be the ones most in need of help? Also, how could one solve the "expatriate bias" when helping people by giving assistance abroad, rather than in their states of origin? Price's in situ principle applies here, ranking above humanitarianism (in receiving states) as a more cost-effective means of advancing the refugee policy's ultimate goal in a context of budgetary limitations. In doing so, he offers another response to whether non-persecuted refugees should also receive permanent protection: (humanitarian) aid relief directed to those who can receive help in her or his state of origin, or in camps along the border, rather than abroad ${ }^{12}$, would - according to him - cost less to meet the needs of people living in the global South than to integrate them into a developed country (limited by finite aid budget).

Noticing that the costs and benefits of admitting different kinds of refugees may vary

11 "If the public perceives that the asylum system is being exploited by "ordinary" immigrants who have no claim to admission, support for asylum will quickly be eroded" (Martin, 1991, p. 35).

12 "The in situ principle applies to persecuted people as well, and explains the widely followed legal doctrine that one is ineligible for asylum if one could safely relocate within one's country of origin" (Price, 2009, p. 180). 
considerably, David Miller differs from both Price and Gibney in his defense of allowing states to select ${ }^{13}$. If some will contribute a lot and need little state support, while for others the opposite may be true, Miller asks the following "is it acceptable for a state to take these costs and benefits into account when it decides on its admission policy?" (2019, p. 99). In the case of refugees, unlike other immigrants, some may think it is unacceptable. By first examining the refugee's perspective, Miller makes a similar distinction as that by David Owen between asylumseekers who need temporary, short-term protection from persecution, and who ought to be given sanctuary, and those who need long-term protection and who therefore need permanent resettlement. The advantage of such an approach is related to the very criteria that establishes that each refugee category requires, analytically, distinctive forms of protection: whereas the obligations toward those requiring sanctuary are determined by the vulnerability and need that the individual faces, those in need of resettlement can be selected in part based on their expected potential for social integration in the asylum state. Despite the fact that these two scenarios (or categories) are inherently blurred in practice, it still might be analytically useful as a selection criterion for refugees. As Miller recognizes, it might be too difficult to devise a policy that captures exactly the morally relevant distinction between refugees whose vulnerability requires shortterm measures, given that their need depends on conflict cessation or a regime change in their home country, and those whose state of origin's long-lasting instability means they only have a chance to make a new life elsewhere. Nevertheless, what is at stake here, in more abstract terms, is the question of how many people in need can be aided given our capacity to respond.

From the receiving state's perspective, it is clear that some consequentialism is crucial to Miller's practical reasoning. The overall costbenefit effect of taking in a certain number of refugees, according to Miller, is a sine qua non condition to be considered when a refugee quota is unilaterally established by a certain state or in an agreement between states. As Miller argues, "some refugees are likely to be costlier than others to receive and integrate, and equally some can be expected to create greater benefits than others as they contribute productively or culturally to the society they have joined" (Miller, 2019, p. 107). This reasoning in terms of interests - according to which the state and its citizens select refugees who are expected to provide the greatest benefits with the lowest cost, using whatever measure of benefit and cost citizens deem to be relevant - echoes somewhat Gibney's lowcost proviso, in the sense that it is acceptable to try to fulfill such state's duties to refugees in the least burdensome way possible. Yet, Miller advances this debate by questioning whether these cost and benefit considerations are legitimate grounds for states to select which refugees to admit. According to him, the dividing line separating legitimate and illegitimate decisions on such grounds depends on the (in)existence of an immediate threat to refugees' human rights. In other words, if they are moving directly from the state where their rights are being threatened to a Western state, only the refugee's degree of vulnerability might be justifiably considered, and under these circumstances, refugees would be legally entitled to more than just

13 Nevertheless, Miller echoes here Gibney and Price's concern for the public goods that societies provide, and which may be jeopardized if states have no say in the selection of refugees. 
basic rights protection. Resettlement cases look rather different because the human rights of the person being granted that status are not necessarily under immediate threat. Here is where Miller's concern lies: once he assumes a contractualist position in which refugees are given the chance to join the social arrangement of a liberal democracy, to have in due course access to the full set of social and political rights that other citizens enjoy, why then would a state not be allowed to ask whether refugees, as with immigrants generally, are likely to be net contributors or net beneficiaries (Miller, 2019)? Miller goes further than our present purposes when he highlights the problem with this proposal from the perspective of the distribution of refugees between states and his defense of a matching system for refugees.

Up to this point, as we have analyzed, legal and moral philosophers worked on the assumption of limited resources in their attempt to formulate a number of legal and moral principles to establish the limits of states' duties towards those who flow into their territories. On this issue, Price points to legal-institutional measures which would both prevent asylum adjudicators to make politically biased decisions on refugee entrance-rejection and (politically) condemn at the international level those who create refugee flows; based on a principle of state's humanitarianism, Gibney supports granting rights and providing goods to refugees at a minimal political cost in order to protect Western governments from any domestic instability caused by a clash between the claims of persons forced displaced (who benefit from the receiving state's resources) and the claims of citizens; Miller, in turn, examines to what extent states might take into account the benefits that one refugee, compared to another, could bring to the receiving society when this selection does not involve immediate life threats to asylum applicants. Concerns with the likelihood of burdensome costs imposed upon developed states are recurrent in a myriad of normative formulations, which argue either the need to protect the citizens' welfare against the refugees' access to a certain community's territory and resources, or the importance of liberal democracies' domestic political stability to the establishment of the entry policies themselves. Such state-centered framework, however, provides a skewed picture of how politics itself may actually reveal other nuances of the phenomenon. While dwelling on the morality and the limits of refugee entrance, analytic philosophers have lost sight of other political dynamics of displacement and refugeehood. I will explore in the next section the way in which Critical Citizenship Studies, mainly a renewed Arendtian tradition, denounces an apolitical humanitarianism approach using their own conceptualization of "the refugee problem" (Saunders, 2018). Even though I do not totally agree with this theoretical approach either, I take advantage of this debate to clarify other political and moral challenges regarding this issue and, consequently, I demonstrate in the end why both philosophical traditions have not offered a sufficient response to the refugees' entitlement to rights.

\section{The Political issue within the "Refugee Problem"}

The humanitarian credentials of the refugee regime have come under scrutiny by different angles, most notably in terms of its claim to be "above politics." Severe criticisms have attempted to demonstrate how humanitarian practices and principles render refugees an undifferentiated mass of victims in need of charity, by abstracting their predicaments from specific political, historical and cultural contexts. Refugees are only made visible (Harrell-Bond, 1986, p. 8) as a means 
to raise resources and the "awareness" that organizations need in order to provide a often life-saving assistance to the povertystricken, traumatized, helpless, incapable of speech and action and in need of a savior (Johnson, 2011; Nyers, 2006; Rajaram, 2002). Regarding this issue, there would be not only a politics of humanitarianism, in the sense that humanitarian management creates and entrenches hierarchies and functions within organizations according to certain rules and practices, but there would also be a fundamentally political dimension in humanitarianism itself. The logic of emergency upon which it rests might be understood as the "tools of statecraft" (Soguk, 1999), which serve the function of "keeping the international system of sovereign states intact by responding to the crises this same system produces in ways which not only fail to challenge, but themselves reproduce, the underlying principles and practices by which it functions" (Saunders, 2018, p. 6). Hence, Soguk (1999) argues, the refugee regime could be seen as part of the sovereign state itself, rather than an "external actor" that would mitigate the effects of "breakdowns" in the functioning of (inter-national) political life.

In light of this criticism, all normative reasoning concerning forced migration we have analyzed earlier reduces refugees to non-political agents who are beneficiaries of the state's humanitarian duties. Such moral approach, therefore, is too often shaped by a very particular apolitical reasoning whose recipient-oriented points of view tend to focus on goods and their distribution, without taking essential aspects of justice into consideration. Regarding this matter, three main issues emerge from analytic philosophers' arguments.
First, they ignore the very issues related to the distribution of goods and how the context of a just organization has emerged; in other words, theories of an allocative or distributive nature usually disregard the issue of power, or more precisely, the political question of how the structures of allocation of goods are determined. Second, their approach disregards the political question of who determines the very structure of goods production and distribution and how it is neglected, although it sees the state as a neutral mechanism whose existence is programmed to correctly use the right "metric" of justice ${ }^{14}$ (Young, 2011). Third, consequently, they all fail to pay attention to the challenges that forced displaced persons have been posing to humanitarian practices within states and organizations by claiming the right to influence their protection policies rather than simply receiving aid with gratitude.

Critical Citizenship Studies have by contrast sought to problematize the status of the citizen as the political agent par excellence to the detriment of those whose legal status makes them "outsiders;" in doing so, they examine the ways in which these actors attempt to both dispute this "humanitarian lenses" through which the refugee regime see them and position themselves in relation their protection policies. Protests by refugees and asylum seekers agitating for rights and employment and acts of resistance such as hunger strikes by imprisoned migrants have all been examined as a form of political agency that challenges the state's prerogative to distinguish between insiders and outsiders i.e. "the drawing of lines between citizens and non-citizens" (Johnson, 2014, p. 196). In this sense, according to Isin and Nielsen (2008), non-citizen "others" perform creative

14 "The distributive paradigm of justice tends to reflect and reinforce this depoliticized public life, by failing to bring issues of decision-making power, for example, into explicit public discussion” (Young, 2011, p. 10). 
"acts of citizenship" in which citizenship is not understood as a formal legal status, but rather as a status derived from a practice that creates citizens. This shift of focus to political action leads to the reconceptualization of citizenship from the territorially bound to the mobile (Nyers; Rygiel, 2012; Squire, 2010).

In this regard, Hannah Arendt has been increasingly remembered by scholars who try to address her broader body of work on refugee studies by discussing the analyses of the systemic origins of forced displacement outlined in The Origins of Totalitarianism. Ayten Gündoğdu (2011) is one of these rare scholars of (forced) migration who has addressed Arendt's entire oeuvre. According to her, the rights of man became enmeshed with the rights of peoples in the European nationstate system until all people were deemed part of a state. Yet, the rise of nationalism, which turned the nation into a new absolute, obliterated the subtle balance between the state as the supreme legal institution charged with the protection of a territory's inhabitants and the nation as a community composed of those who belong by right of origin and birth (Gündoğdu, 2011). Insofar as the "citizen" was reduced to the "national," and the state gradually lost its representative function, it became evident, Gündoğdu conlcudes, that not all people in Europe did belong to a state, despite their physical presence within one state or another.

More important for this debate is Natasha Saunders' (2018) understanding of a cosmopolitan Arendt whose unique conceptualization of "the world" and how people come to be "at home" in it would be key aspects for her continued relevance to addressing "the refugee problem." Saunders thus argues for the need of situating the roots of these various practices in light of two political dimensions: "the refugee (as) problem" and the "refugees' problems" (in their own terms).
I present next Saunders' argument in defense of the political rights of refugees; then, I seek to demonstrate why internal contradictions within her interpretation of a cosmopolitan Arendt weaken her own normative claims.

\section{Worldlessness and the Refugees' Problem}

The 1951 Refugee Convention (as amended by its 1967 Protocol) and the UNHCR were established in order to solve what has been understood as "the refugee problem." But what actually does "the refugee problem" mean? The relevance of this question, Saunders argues, is inextricably related to the fact that to "solve" a problem, and to measure the solutions' success, is dependent upon what we understand that problem to be. If we recognize that there may not be just one "refugee problem" but so many problems as political actors (the UNHCR, receiving states, humanitarian organizations) who engage with it, then we must ask to which "problem" the refugee regime was conceived to propose solutions. This is how Saunders points out the risk such regime faces in addressing problems out of its domain and the possibility that these problems may clash with each other. In other words, if a given state, or an international organization, operating on a humanitarian-principle basis fails to protect the rights of foreigners, that is not because they disingenuously appeal to the refugee problem as a mere excuse for harming these persons; rather than starting from such naïve assumption, what Saunders' discusses is the very impossibility of political institutions understanding such problem from the refugee's point of view, if forced displaced persons remain politically voiceless. At this point, Saunders calls attention to the (conceptual, political and normative) importance of distinguishing between "the problems that refugees face and the problems that refugees pose" (Saunders, 2018, p. 4). While these 
two problems are undoubtedly connected, as Saunders recognizes, in that displacement poses a problem not only to the international community but also to the displaced themselves, "it is far from clear, although it is often assumed, that solving the problem that refugees pose results automatically, or unproblematically, in solving the problems that refugees face" (Saunders, 2018, p. 4). The need to understand these two problems separately has to do with the very implications of addressing "the refugee problem" by using one approach or another ${ }^{15}$. Once this alternative account is provided, Saunders starts developing a sort of "individual cosmopolitanism," in the light of which granting political rights to refugees is a necessary condition to not only solve the refugeehood problem, globally and domestically, but also to transform the meaning attributed to citizenship.

As I mentioned above, Saunders revisits Arendt's well-known analysis of the structural causes of displacement within the context of her philosophical and political reflections on the "world" to clarify how this structural problem becomes a personal problem for those who are subjected to this process, suggesting that this should be understood as "worldlessness" and "superfluidity" in Arendtian terms. She then uses these reflections to show why repatriation, resettlement and local integration, the three current durable solutions to displacement, are supposedly insufficient formal remedies, focused on structural problems rather than existential ones, to address the problems that being a refugee presents for those that are outside the state-citizen-territory boundaries. In light of this, Saunders denies that the "rights to have rights" should be reduced to the right to citizenship within the nation-state. For her, this simply ignores the problems that Arendt also addressed regarding citizenship and politics in modernity for all people, not just the stateless, thus arguing that we should re-imagine the very nature of the communities to which such a right would supposedly correspond. This context, in which the problems that refugees face are located, reflects then not a terminology of a certain list of formal rights in itself, but rather the loss of a place in the world to make opinions significant and actions effective. In short, losing the significance of opinions and the effectiveness of actions correspond to a loss of a kind of "place" in the world and, consequently, of the ways in which such a place might be reclaimed.

If the reality of the world is only guaranteed by the presence of others, and is an ephemeral "product" of human action and speech, plurality is the necessary condition by means of which "we insert ourselves into the human world, and this insertion is like a second birth, in which we confirm and take upon ourselves the naked fact of our original physical appearance" (Arendt, 1998, p. 177). In spite of the intentions and goals driving our actions, a pre-existing web of relationships, within which others then re-act, makes humans dependent upon others to act in pursuit of their projects $^{16}$. Hence, Saunders argues, both action and speech (opinion) are inextricably linked to the presence and recognition of a diversity of "others" of whom we form opinions to act in the world and, consequently, are necessary to turn those opinions and actions into something meaningful to them. In this sense, the unprecedented loss that refugees suffer exceeds the loss of their home, that is, the "entire

15 “[...] shifting our focus to refugees' problems - the problems that refugees face - necessitates a quite different approach to the 'population management' orientation of 'the refugee (as) problem"' (Saunders, 2018, p. 4).

16 This is what Arendt (1998) refers to as the interdependence of action). 
social texture" into which they were born and "in which they established for themselves a distinct place in the world" (Arendt, 1986, p. 293): it is "the impossibility of finding a new one" (Arendt, 1986, p. 294). As states have left no empty spot on earth where the stateless could go, this reality reflects not simply a geographical problem, but rather a problem of political space. In Arendt's terms, humanity has "reached the stage where whoever was thrown out of one of these tightly organized closed communities found himself outside of the family of nations altogether" (Arendt, 1986, p. 294). That initial loss of home, compounded by the loss of government protection, which turns out to be the loss of legal status in all countries, ultimately means the expulsion from humanity. If whatever refugees say or do fail to be recognized by others as events to which one responds in the co-constitution of the common world ${ }^{17}$, Saunders argues it is only through the achievement of equality that such persons could overcome the worldless existence they live in ${ }^{18}$.

As a result, all efforts aimed at "solving the problem" by enumerating new declarations of rights seem to be hopelessly inadequate, because the very declaration of rights has unavoidably failed to grasp one crucial dimension of this issue: "it was not the loss of specific rights but the loss of a community willing and able to guarantee any rights whatsoever that had been the calamity of everincreasing numbers of people" (Arendt, 1986, p. 297). The fundamental deprivation of human rights is manifested "first and above all in the deprivation of a place in the world which makes opinions significant and actions effective" (Arendt, 1986, p. 296). In light of this conceptual framework, the refugee status is nothing but a poor substitute for enjoying the legal personhood necessary to enable a truly worldly existence, largely because such legal personhood - i.e. the equality that we enjoy as recognized members of political communities - should first and foremost endow our actions with a meaning that they would otherwise lack as expression of plurality; such legal personhood, ultimately, is not bound to a juridical tie between an individual and a state, but more importantly, "it is an artificial convention that institutes relationships among different individuals" (Gündoğdu, 2015, p. 105). That implies that that formal legal status cannot always be such a guarantee. According to Saunders, the refugee status may, on paper, provide formal access to important socio-economic rights that can help refugees regain a foothold in another political community, while it cannot provide the right conditions to ensure one's access to the political realm of action and speech i.e. the access to the inter-subjective world of collective remembrance.

As UNHCR is mandated to assist refugees in accessing a durable solution, but cannot itself provide such a solution, Saunders argues that "neither the durable solutions, nor the cessation clause, appear to be about the possibility of effective citizenship, but about finding places to put people [...]" (Saunders, 2018, p. 136). Such durable solutions then reinforce the idea that refugee protection, despite its relative contribution in alleviating the problems that refugees face, corresponds to mere gifts of host

17 This explains why Arendt (1986, p. 296) downgrades the "freedom of opinion" retained by refugees as "a fool's freedom, for nothing that they think matters anyhow". In short, their opinions are treated as of no consequence for anyone else.

18 Equality, Arendt (1986, p. 301) writes, "is not given us, but is the result of human organization [...] We are not born equal; we become equal as members of a group on the strength of our decision to guarantee ourselves mutually equal rights". 
states. In Foucault's terms, it is about managing populations rather than solving the problems of worldlessness and refugeehood. Moreover, the underlying logic of solving "the refugee (as) problem" would reflect "the rules of the refugee regime to become complicit in making the refugee worldless and superfluous once again by leaving any such progress made by the refugee open to destruction once more" (Saunders, 2018, p. 136). The strongest evidence of her claim stems from the many cases in which the cessation clauses (of the refugee status) have been applied in practice, mainly in Southern states, resulting in uncertain legal status and vulnerability to arbitrary arrest and imprisonment, forced repatriation to unsafe circumstances and economic and social deprivation on the part of refugees whose recognition has been removed (Siddiqui, 2011).

At the same time, Saunders recognizes that conceptualizing the "right to have rights" as citizenship in the nation-state is not unproblematic, largely due to a legalistic understanding of human rights that, on her view, Arendt should have expressly rejected ${ }^{19}$. In my view, there is another deeply disputable issue in Saunders' understanding of legality on Arendtian terms. In the next subsection, I argue why such strong reliance on a cosmopolitan citizenship is not feasible, first and foremost because supporting the very idea of law (nomos) in Arendt's terms unavoidably corresponds to addressing the space and the politics of boundaries.

\section{Nomos and the problem of spatial unity}

Saunders disregards two crucial dimensions involved in the co-constitution of citizenship: the genesis of a political community, through which certain interests of legal protection are simply deemed more relevant than others by its members, and the setting of boundaries that define where behaviors ought or not to take place. To clarify the weaknesses within her argument for the equality of political rights between citizens and non-citizens, suppose another reading of Arendt's theory, one in which, regardless of whether globalization is a political desideratum, the dissolution of nation-states into a world state is a possibility that has come within the reach of humanity (Lindahl, 2006). First of all, we need to consider how the law, in practice, plays a constitutive and reflexive role in politics and in the political community when Arendt recovers the original spatial meaning of nomos. The law of the polis "was quite literally a wall, without which there may have been an agglomeration of houses, a town (asty), but not a city, a political community. This wall-like law was sacred, but only the in- closure was political" (Arendt, 1998, p. 63-64). But Arendt goes much further, generalizing the original Greek understanding of the law as a constitutive feature of a political community as such: "all legislation creates first of all a space in which it is valid [...]" (Arendt, 1998, p. 49). In this sense, what lies outside this space is lawless and, properly speaking, without a world (Arendt, 2003, p. 122).

The reason why nomos deserves a conceptual and political priority over other derivative conceptions of law is the innate boundlessness of action, which nomos "prevents [...] from evaporating into an unsurveyable (unübersehbaren), continuously growing system of relations" (Arendt, 1998, p. 198). The need for grounding the nomos becomes even more evident if we consider what might possibly be

19 "Her critique of rights [...] turns on the observation that absent a community willing and able to guarantee rights [...] we are rightless, regardless of whether, on paper, we possess a legal status which entitles us to such rights" (Saunders, 2018, p. 136). 
Arendt's most trenchant statement about this concept as taken from the Greeks: "Freedom, wherever it has existed as a tangible reality, has always been spatially limited" (Arendt, 1986, p. 275). To put it provocatively, citizenship issues from nomos because if it primarily depends on inclusion, likewise there can be no such status without exclusion, which means citizenship is fundamentally topical. How then could we understand such spatial unity - that is, limitation - if not in light of the constitutive character of nomos in a political community? The problem is that "by postulating that plurality is the conditio per quam of speech and action, and of politics in general," as Hans Lindahl points out, "Arendt relegates the legal enclosure of space to a merely 'prepolitical' condition of action” (Lindahl, 2006, p. 885).

Now that I briefly presented the main elements for supporting my perspective of the limits of citizenship, let me restate the idea of a world state from another angle. In effect, a reflexive approach implies that the reliance of a political community on delimiting its own space is a constitutive feature. In asserting that even in modern conditions there is an "elementary coincidence of freedom and a limited space," Arendt drives home this point by noting that "freedom in a positive sense is possible only among equals, and equality itself is by no means a universally valid principle but, again, applicable only with limitations and even within spatial limits" (Arendt, 1986, p. 275). Here, the institution of a global political equality simply means, on the one hand, that the world citizen would be held committed to the world state's common interests in respecting the boundaries of what counts as being in a legal place and, on the other hand, the possibility of the existence of political inequalities that could ultimately lead the world citizenship to be withdrawn from those who radically contest the polity's claim to a common place. But the question, strange though it may seem, is the following: Would there be a place for asylum if citizens were to forfeit their citizenship in a world state?

Even considering (a) a world state scenario far from any reality, Saunders could very well base her response on a Lindahl's passage according to which political asylum is "a technique that uses the distinction between own and foreign places to counter the tendency of political communities to deny (the contingency of) the divide they set up between own and strange places" (Lindahl, 2006, p. 891); asylum would not therefore dissolve into a boundless political equality, but rather be transformed into another political process through which dissidents would never lose the political rights enjoyed by all, which means that asylum might also serve for calling attention to the existence of strange places within the space a polity claims to be its own territory. Another possible response, Saunders could argue, would be that (b) her approach never moved into, nor at least suggested, the foregoing scenario; instead, given that she has clearly focused on the international refugee regime in today's global politics, her argument rests on guaranteeing refugees political rights on both consequential and instrumental grounds. First, she claims that the refugees' political participation necessarily enhances democracy itself within a given society insofar as plurality is a sine qua non condition of the manner in which members (citizens and refugees) co-constitute the world through action and speech. On this issue, the political engagement of refugees "serves" as a metric for citizenship as well, in the sense that refugeehood could at least potentially call into question the merely formal aspect to which legal membership was relegated and, as a result, refugee political rights could produce positive knock-on effects on the citizen practices themselves, and consequently on the quality of democracy in the host society. 
To refute (a), suffice it to say that the very realization of global freedom would be unimaginable unless the Earth becomes nomos on a planetary scale ${ }^{20}$. In a nutshell, even supposing the existence of a world state, whatever its political organization, there would be no escape from the latent possibility of secession and, concomitantly, reinstatement of the distinctions between own and foreign territories, citizen and foreigner. "It is no coincidence," Lindahl argues, "that the foundational act of a political community not only separates an inside from an outside but also identifies who counts as a citizen" (Lindahl, 2006, p. 892). Hence, the way in which Saunders often argues for the immediate political assimilation of forced displaced people contradicts her own normative formulation: if, as implicit in her claim, she assumes a boundless political community, she ambiguously falls into an internal paradox, that of either supporting refugee political rights in a world state context, which is not possible in our current terms, or taking the borders control from the state's hands, which obliterates the constitutive character of a political community itself, fundamentally grounded as it is on citizenship.

Likewise, I am not convinced that (b) is a compelling reason. Saunders' support of refugee political rights strongly relies on the assumption that the rights and benefits attached to refugee status "have not changed significantly since the conventions with which Arendt was familiar from the inter-war years" (Saunders, 2018, p. 133). Notwithstanding her acknowledgement of how differently these rights come into effect in each state nowadays, Saunders leaves aside the fact that refugeehood is neither morally nor phenomenologically the same as before. Whereas the bulk of asylum seekers were in Arendt's times could somewhat count on legally binding duties to be given protection against persecution, current debates on the moral status of refugee entitlement have immensely complicated this task. Suppose we now adopt Schacknove's influential definition (III) of refugees, in order to test Saunders' argument: Is it possible to also grant political rights to every human being in the world living under dire social conditions and deprived of human rights? Saunders' claim have to face therefore an inescapable issue: either a political community "fairly" provides political rights to all refugees, without distinguishing one case from another, or it "wrongfully" denies them all. If the former alternative is seemingly the most reasonable one, then why are all immigrants not granted the same rights upon their arrival?

There is no clear evidence supporting her idea that granting political rights to all refugees will necessarily and substantively enhance democracy within the host society. Saunders' claim is equally problematic because she employs a conclusion as a premise by arguing that the granting of citizenship to the forced displaced are a necessary precondition of the "right to have rights." Nonetheless, her denouncement of the wrongs that states have been committing in their selection criteria of refugees and entry policies traces this debate back to a crucial domain: the inescapable role of politics on matters of refugeehood and entrance decisions.

\section{Conclusion}

In taking Natasha Saunders as an example of political approach, one of my goals was to shed light on how she attempts to avoid the moral and legal difficulties of these issues by

20 "[...] although global freedom, beginning with the freedom of movement, would be unthinkable without the concrete distribution of places made available by a territory, this distribution of places also opens up the world state to the charge that freedom is elsewhere, in another world" (Lindahl, 2006, p. 891). 
blurring the line that analytic philosophers have strived to drawn: the question of "who is entitled to refugee status?" One of the few alternatives for someone like her who adopts an Arendtian approach is to reduce rights to a mere by-product of legal formalities and to conceive of legal personhood in inter-subjective terms (or rather, "performatically"). That leads to an ambivalent consequence. Saunders and other scholars of the same theoretical tradition are rightly able to criticize the "politically apolitical" character of humanitarianism based on which analytic philosophers have often formulated a normative principle for refugeehood (Carens, 2013; Gibney, 2004; Miller, 2016; Price, 2009). By doing so, she also leaves open an insightful perspective on the formulation of refugee rights in light of the "refugees' problem" (in contrast with the "refugee as problem"). In other words, her argument for the longneeded rights is based not only on top-down Conventions, but also on bottom-up procedures and structures of individual right claims.

Yet, such an approach becomes problematic in a number of ways. First, Saunders and other Arendtian scholars (Gündoğdu, 2011) equally fall into a definitional problem of what politics actually is - or means. Once politics is taken as a normative idea, this theoretical tradition cannot avoid framing the political dynamics, ultimately, as a teleological consensual practice.
Otherwise, any claim about the value of plurality is under the threat of agonism, and the dissolution of the polis would always be on the horizon. Wouldn't there be other ways of responding to refugee issues?

Moral philosophers, by contrast, have fallen into the above-mentioned "apolitical" character of humanitarianism. Even someone like Gibney, who builds upon a low-cost proviso for Western states' duties - by taking as independent variable the state (government) as a moral agent in light of unemployment, ethical-cultural affinities and other dependent variables - cannot help doing the same. Either we consider a strong statist thesis that the state is the unique normative trigger, or we consider the weak statist thesis that the state is necessary to trigger equal consideration in particular, the remaining question is: What about those who are excluded from this justice-generating domain (the state)? For philosophers like Miller, Gibney and Price, providing aid to povertystricken people who can be helped in situ turns out to be the more efficient way of protecting human rights globally. Their exclusive focus on developed countries, however, leads them to insulate the state from the global setting, which means that intergovernmental relations as well as international politics have little effect on such analyses of states' ethical decisions on entry policies.

\section{References}

ARENDT, H. The Human Condition. Chicago: University of Chicago Press, 1998.

ARENDT, H. The Origins of Totalitarianism. London: Andre Deutsch, 1986.

ARENDT, H. Was ist Politik? Fragmente aus dem Nachlaß. Munich: Piper, 2003.

CARENS, J. The Ethics of Immigration. New York: Oxford University Press, 2013. 
GAMMELTOFT-HANSEN, T.; HATHAWAY, J. Non-refoulement in a World of Cooperative Deterrence. Law and Economics Working Papers, paper 106, Aug. 2004. Available from: <http://repository.law.umich.edu/ law_econ_current/106>.Access in: 24 Apr. 2019.

GIBNEY, M. J. The Ethics and Politics of Asylum: Liberal democracy and the response to refugees. Cambridge: Cambridge University Press, 2004.

GÜNDOĞDU, A. Perplexities of the Rights of Man: Arendt on the Aporias of Human Rights. European Journal of Political Theory, v. 11, n. 1, p. 4-24, Sep. 2011. https://doi.org/10.1177\%2F1474885111417781

GÜNDOĞDU, A. Rightlessness in an Age Of Rights: Hannah Arendt and the Contemporary Struggles of Migrants. Oxford: Oxford University Press, 2015.

HADDAD, E. The Refugee in International Society: Between Sovereigns. Cambridge: Cambridge University Press, 2008.

HARRELL-BOND, B. Imposing Aid: emergency assistance to refugees. Oxford: Oxford University Press, 1986.

HATHAWAY, J. C. The Rights of Refugees Under International Law. Cambridge: Cambridge University Press, 2005.

ISIN, E.; NIELSEN, G. (ed.). Acts of Citizenship. London: Zed Books, 2008.

JOHNSON, H. Borders, Asylum, and Global Non-Citizenship: The Other Side of the Fence. Cambridge: Cambridge University Press, 2014.

JOHNSON, H. Click to donate: visual images, constructing victims and imagining the female refugee. Third World Quarterly, v. 32, n. 6, p. 1015-1037, Jun. 2011. https://doi.org/10.1080/01436597.2011.586235

LINDAHL, H. Give and take: Arendt and the nomos of political community. Philosophy \& Social Criticism, v. 32, n. 7, p. 881-901, Nov. 2006. https://doi.org/10.1177\%2F0191453706066979

LOESCHER, G. (ed.). Refugees in International Relations. Oxford: Oxford University Press, 2010.

MARTIN, D. A. The Refugee Concept: on definitions, politics, and the careful use of a scarce resource. In: ADELMAN, H. (ed.). Refugee Policy: Canada and the United States. Toronto: York Lanes Press, 1991. p. 30-51.

MENEZES, L. B. da S. The Morality of Encampment: refugeehood, politics and global justice. Master Thesis (Sciences Po) - Institut d'études politiques, Paris, 2020. Available at: https://uspc-spo.primo.exlibrisgroup.com/ discovery/fulldisplay?docid=alma991007146773705808\&context=L\&vid=33USPC_SPO:SPO\&lang=fr\&search_ scope=MyInst_and_CI\&adaptor=Local\%20Search\%20Engine\&tab=Everything\&query=any,contains,Leonardo\% 20Barros\%20da\%20silva\%20menezes\&offset=0. Access in: 27 Jul. 2020.

MILLER, D. Selecting refugees. In: MILLER, D.; STRAEHLE, C. (ed.). The Political Philosophy of Refugee. Cambridge: Cambridge University Press, 2019. p. 97-113. 
MILLER, D. Strangers in Our Midst: The Political Philosophy of Immigration. Cambridge: Harvard University Press, 2016.

NYERS, P. Rethinking Refugees: Beyond States of Emergency. London: Routledge, 2006.

NYERS, P.; RYGIEL, K. (ed.). Citizenship, Migrant Activism and the Politics of Movement. London: Routledge, 2012.

PRICE, M. E. Rethinking Asylum: History, Purpose, and Limits. Cambridge: Cambridge University Press, 2009.

RAJARAM, P. K. Humanitarianism and Representations of the Refugee. Journal of Refugee Studies, v. 15, n. 3, p. 247-264, Sep. 2002. https://doi.org/10.1093/jrs/15.3.247

SAUNDERS, N. International Political Theory and the Refugee Problem. New York: Routledge, 2018.

SHACKNOVE, A. Who is a refugee? Ethics, v. 95, n. 2, p. 274-284, Jan. 1985. https://doi.org/10.1086/292626

SIDDIQUI, Y. Reviewing the application of the Cessation Clause of the 1951 Convention relating to the status of refugees in Africa. Refugee Studies Centre Working Paper Series, n. 76, p. 4-52, Aug. 2011. Available from: <https://www.rsc.ox.ac.uk/files/files-1/wp76-reviewing-application-cessation-clause-1951-convention-2011.pdf>. Access in: 5 May 2020.

SOGUK, N. States and Strangers: Refugees and Displacements of Statecraft. Minneapolis: University of Minnesota Press, 1999.

SQUIRE, V. (ed.). The Contested Politics of Mobility: Borderzones and Irregularity. London: Routledge, 2010.

UNITED NATIONS HIGH COMMISSIONER FOR REFUGEES. Beware long-term damage to human rights and refugee rights from the coronavirus pandemic. UNCHR, 22 Apr. 2020. Available from: <https://www.unhcr.org/news/ press/2020/4/5ea035ba4/beware-long-term-damage-human-rights-refugee-rights-coronavirus-pandemic.html>. Access in: 17 Jun. 2020.

UNITED NATIONS HIGH COMMISSIONER FOR REFUGEES. UNHCR Resettlement Handbook. Geneva: UNHCR, 2011.

WALZER, M. Spheres of Justice. New York: Basic Books, 1983.

YOUNG, I. M. Responsibility for Justice. Oxford: Oxford University Press, 2011.

\begin{abstract}
Refugeehood and rights: A theoretical debate

To which rights refugees are entitled? In this paper, I analyze the many challenges that two interrelated theoretical traditions of Refugee Studies have implicitly posed to one another. First, I examine the analytic philosophers' assumption
\end{abstract}


that we cannot understand the nature of a refugee claim until we know what entitles an individual to make it - i.e., what root cause for displacement could explain, and justify, such status. Second, after examining Critical Citizenship Studies, I mainly discuss a renewed Arendtian tradition whose cosmopolitan claim has advocated granting the right of citizenship to all forced displaced persons. By demonstrating why each response leaves room for strong rebuttals from the other side, I make clear the urgency of rethinking today's international refugee regime as well as the place of political theory in it.

Keywords: Justice; Human rights; Refugee; Forced displacement; Humanitarianism.

\section{Resumo}

\section{Estatuto de refugiado e direitos humanos: um debate teórico}

A que direitos têm direito os refugiados? Neste artigo, analiso os muitos desafios que duas tradições teóricas relacionadas aos Estudos sobre Refugiados implicitamente puseram uma à outra. Em primeiro lugar, começo por avaliar o pressuposto dos filósofos analíticos de que não podemos compreender a natureza de uma reivindicação de refugiado enquanto não soubermos o que habilita um indivíduo a fazê-la, ou seja, qual a causa para o deslocamento forçado poderia explicar e justificar tal estatuto. Em segundo lugar, após examinar os Estudos de Cidadania Crítica, discuto principalmente a renovação de uma tradição arendtiana, cuja reivindicaçáo cosmopolita tem defendido o direito irrestrito de cidadania a apátridas. Ao demonstrar por que razáo cada resposta deixa espaço para fortes refutaçóes do outro lado, explicito a urgência de se repensar o atual regime internacional de refugiados, bem como o lugar da teoria política no mesmo.

Palavras-chave: Justiça; Direitos humanos; Refugiados; Migração forçada; Humanitarismo.

\section{Résumé}

\section{Le statut de réfugié et les droits de l'homme : un débat théorique}

A quels droits les réfugiés peuvent-ils prétendre ? Dans cet article, j’analyse les nombreux défis que deux traditions théoriques interdépendantes des études sur les réfugiés se sont implicitement posés l'une à l'autre. Tout d'abord, j'examine l'hypothèse des philosophes analytiques selon laquelle nous ne pouvons pas comprendre la nature d'une demande de statut de réfugié tant que nous ne savons pas ce qui permet à un individu de la faire - c'est-à-dire, quelle cause profonde de déplacement pourrait expliquer et justifier un tel statut. Après avoir examiné les études critiques sur la citoyenneté, je discute principalement d'une tradition arendtienne renouvelée dont la revendication cosmopolite a préconisé l'octroi du droit de citoyenneté à tous ceux qui sont déplacés. En démontrant pourquoi chaque réponse laisse place à de fortes réfutations par l'autre partie, je rends explicite l'urgence de repenser le régime international des réfugiés d'aujourd'hui ainsi que la place de la théorie politique dans ce régime.

Mots-clés : Justice ; Droits de l’homme ; Réfugié ; Déplacement forcé ; Humanitarisme. 